\title{
Analisis kemampuan pemecahan masalah matematika ditinjau dari tingkat self-confidance peserta didik kelas VIII
}

\section{Rani Rizka Ramdani ${ }^{1}$, Nyoman Sridana ${ }^{2}$, Baidowi ${ }^{2}$, Laila Hayati $^{2}$}

\author{
${ }_{1}$ Mahasiswa Pendidikan Matematika, FKIP, Universitas Mataram, Mataram \\ ${ }_{2}^{2}$ Pendidikan Matematika, FKIP, Universitas Mataram, Mataram \\ ranirizka.ra@gmail.com
}

Diterima: 8 Juni 2021; Direvisi: 29 Juni 2021; Dipublikasi: 30 Juni 2021

\begin{abstract}
This study aims to describe mathematical problem-solving ability based on the level of self-confidence. This type of research is a qualitative descriptive study with a quantitative approach. The data collection technique in this research is to provide test (10 multiple choice questions and 2 description questions), questionnaires, and interviews. The results showed that students with high level of self-confidence with high mathematical problem-solving abilities were able to achieve 3 out of 4 indicators of assessing problem solving abilities well, namely indicators of understanding problems, devising a plan, and carrying out the plans. Students with high level of self-confidence with moderate math problem solving abilities are able to achieve 1 of 4 indicators well, namely carrying out the plans, achieve 2 of the 4 indicators quite well, namely indicators of understanding problems and devising a plan, and less able to achieve 1 of 4 indicators namely looking back indicators. Students with high level of self-confidence with low math problem solving abilities are able to achieve 1 of 4 indicators well, namely indicators of understanding the problem. However, it does not reach 3 indicators, namely devising plans, is carrying out the plan and looking back.
\end{abstract}

Keywords: Qualitative Descriptive Research, Quantitative Approach

\begin{abstract}
Abstrak
Penelitian ini bertujuan untuk mendeskripsikan kemampuan pemecahan masalah matematika ditinjau dari tingkat self-confidance. Jenis penelitian ini adalah deskriptif kualitatif dengan pendekatan kuantitatif. Teknik pengumpulan data pada peneitian ini dengan memberikan soal tes (10 soal pilihan ganda dan 2 soal uraian), kuisioner, dan wawancara. Hasil penelitian menunjukkan bahwa peserta didik dengan tingkat selfconfidance tinggi dengan kemampuan pemecahan masalah matematika tinggi mampu mencapai 3 dari 4 indikator penilaian kemampuan pemecahan masalah dengan baik yaitu indikator memahami masalah, menyusun rencana, dan melaksanakan rencana. Peserta didik dengan tingkat self-confidance tinggi dengan kemampuan pemecahan masalah matematika sedang mampu mencapai 1 dari 4 indikator dengan baik yaitu indikator melaksanakan rencana, mencapai 2 dari 4 indikator dengan cukup baik yaitu indikator memahami masalah dan menyusun rencana, dan kurang mampu mencapai 1 dari 4 indikator yaitu indikator memeriksa kembali. Peserta didik dengan tingkat self-confidance tinggi dengan kemampuan pemecahan masalah matematika rendah mampu mencapai 1 dari 4 indikator dengan baik yaitu indikator memahami masalah. Namun tidak mencapai 3 indikator yaitu menyusun rencana, melaksanakan rencana dan memeriksa kembali.
\end{abstract}

Kata Kunci: Penelitian Deskriptif Kualitatif, Pendekatan Kuantitatif 


\section{PENDAHULUAN}

Pendidikan pada dasarnya merupakan suatu upaya untuk memberikan pengetahuan, wawasan, keterampilan, dan keahlian tertentu terhadap individu-individu guna mengembangkan bakat serta kepribadian sehingga mampu menghadapi setiap perubahan yang terjadi akibat adanya kemajuan ilmu pengetahuan dan teknologi. Dalam dunia pendidikan, matematika adalah salah satu mata pelajaran yang diajarkan di sekolah dengan tujuan agar peserta didik mampu memahami konsep matematika, menjelaskan keterkaitan antar konsep, mengaplikasikan konsep secara akurat, efisien serta tepat dalam pemecahan masalah. Namun, baik dari proses pembelajaran ataupun hasil belajar peserta didik terhadap matematika masih ditemukan beberapa masalah. Dibawah ini disajikan data hasil pembelajaran matematika berupa hasil ujian tengah semester ganjil untuk kelas VIII tahun pembelajaran 2019/2020.

Tabel 1 Rerata Nilai UTS Matematika Tahun Pelajaran 2019/2020

\begin{tabular}{ccc}
\hline No. & Kelas & Rerata Nilai \\
\hline 1. & VIII A & 77.4 \\
2. & VIII B & 57.3 \\
3. & VIII C & 73.6 \\
4. & VIII D & 69.6 \\
5. & VIII E & 62.3 \\
6. & VIII F & 43.1 \\
7. & VIII G & 34.5 \\
8. & VIII H & 49.5 \\
9. & VIII I & 48.5 \\
10. & VIII J & 36.3 \\
11. & VIII K & 33.7 \\
\hline (Sumber: Daftar nilai guru matematika)
\end{tabular}

Tabel 1 menunjukkan bahwa rerata hasil ujian tengah semester ganjil matematika sangatlah bervariasi. Rerata nilai tertinggi dari 11 kelas VIII yang ada adalah 77.3 yaitu kelas VIII A dan nilai rerata terendah adalah kelas VIII K 33.7. Namun, data di atas menunjukkan tidak ada kelas yang mencapai nilai ketuntasan dengan Kriteria Ketuntasan Minimal (KKM) 80.

Berdasarkan hasil wawancara dengan guru pemangku mata pelajaran matematika dan peserta didik, dapat disimpulkan bahwa peserta didik kesulitan untuk menyelesaikan dan memecahkan soal matematika dalam bentuk soal non rutin seperti soal cerita. Peserta didik cenderung menghafal rumus, bukan memahami konsep. Saat menyelesaikan soal cerita, peserta didik tidak hanya dituntut untuk memiliki keterampilan dalam berhitung saja, namun memperhatikan proses penyelesaiannya terutama pemahaman peserta didik terhadap konsep yang digunakan dalam menyelesaikan soal cerita yang diberikan. Kesulitan yang dialami dalam menyelesaikan soal diakibatkan karena siswa kurang cermat dan kesulitan memahami cerita sehingga siswa sulit dalam membuat model matematika dan menemukan konsep yang tepat. Hal 
tersebut nanti akan berpengaruh terhadap kemampuan pemecahan masalah matematika yang dimiliki oleh peserta didik.

Kemampuan pemecahan masalah dapat dimiliki oleh peserta didik apabila guru melatihnya dengan efektif dikarenakan kemampuan pemecahan masalah tidak dapat timbul begitu saja, melainkan harus dilatih (Fitri, dkk, 2017). Pada saat memecahkan suatu masalah diperlukan strategi atau langkah-langkah yang sistemasis yang akan membuat peserta didik mampu memecahkan masalah atau soal tersebut. Tahapan pemecahan masalah yang digunakan pada penelitian adalah tahapan pemecahan masalah menurut Polya, meliputi: (1) memahami masalah, (2) menyusun rencana, (3) melaksanakan rencana, dan (4) memeriksa kembali (Chairani, 2016).

Menurut Suryanti (2015), bahwa untuk memiliki kemampuan pemecahan masalah, peserta didik harus ada sikap positif. Sikap positif ini adalah sikap yakin akan segala kemampuan dan potensi yang dimiliki untuk mampu menghadapi segala hambatan atau menyelesaiakan suatu persoalan yang sedang dihadapi. Sikap positif yang dimaksudkan adalah self-confidance (kepercayaan diri). Suryanti berpendapat bahwa kepercayaan diri dan kemampuan memecahkan masalah sangat erat kaitannya. Self-confidance ini nantinya berperan penting dalam keberhasilan peserta didik untuk memecahkan suatu permasalahan yang diberikan.

Menurut Willis (dalam Ghufron dan Risnawati, 2014), self-confidance adalah keyakinan seseorang akan kemampuan untuk mengatasi suatu masalah dengan situasi yang terbaik. Rahmat (dalam Siska, 2003) menyatakan bila orang merasa rendah diri, akan mengalami kesulitan untuk mengkomunikasikan gagasannya pada orang lain yang dihormatinya dan takut berbicara di depan umum karena takut orang lain menyalahkannya. Sedangkan peserta didik memiliki self-confidance dengan baik, maka peserta didik dapat membangkitkan rasa percaya diri dengan motivasi dan memberikan peluang untuk mampu memecahkan masalah yang dihadapi. Individu yang percaya diri dapat menggunakan strategi terbaik untuk menyelesaikan suatu masalah, individu yang percaya diri juga memiliki kemampuan untuk mencapai target tertentu sesuai yang direncanakan. Hal itu menunjukkan bahwa self-confidance mendukung peserta didik dalam menyelesaikan atau memecahkan suatu masalah.

Setiap peserta didik memiliki tingkat self-confidance yang berbeda-beda. Peserta didik yang memiliki kepercayaan diri tinggi cenderung berani dan yakin akan kemampuan diri yang dimiliki sehingga dapat memecahkan suatu permasalahan dengan baik.

Adapun permasalahan dalam penelitian ini adalah bagaimana kemampuan pemecahan masalah matematika ditinjau dari tingkat self-confidance peserta didik kelas VIII . Tujuan dari penelitian ini adalah untuk mendeskripsikan kemampuan pemecahan masalah matematika ditinjau dari tingkat self-confidance peserta didik kelas VIII. 


\section{METODE PENELITIAN}

Penelitian ini dilaksankan pada peserta didik kelas VIII K pada semester ganjil Tahun Pelajaran 2020/2021. Penelitian ini tergolong penelitian deskriptif kualitatf dengan pendekatan kuantitatif. Penelitian deskriptif adalah penelitian yang dimaksudkan untuk menyelidiki keadaan, kondisi, situasi, peristiwa yang hasilnya dipaparkan dalam bentuk laporan penelitian (Arikunto, 2012). Dalam penelitian ini, untuk memperoleh data yang lengkap sesuai dengan yang diperlukan, teknik pengumpulan data yang digunakan adalah memberikan tes (soal pilihan ganda dan soal uraian), angket, dan wawancara. Menurut Riduwan (2013), teknik pengumpulan data merupakan teknik atau cara-cara yang dilakukaan oleh peneliti untuk mengumpulkan data yang mendukung penelitian Sehingga untuk menunjang pegumpulan data pada penelitian ini instrumen yang diberikan yaitu berupa tes, angket atau kuisioner dan wawancara. Teknik tes dalam penelitian ini berupa pemberian tes (10 soal pilihan ganda dan 2 soal uraian) mengenai materi sistem persamaan linier dua variabel. Angket atau kuisioner digunakan untuk mengukur tingkat self-confidance yang dimiliki peserta didik dengan 16 butir pernyataan yang harus diisi oleh peserta didik. Untuk mempertegas jawaban peserta didik terkait tes kemampuan pemecahan masalah dan angket self-confidance yang telah dijawab kemudian akan dilakukan wawancara.

Instrumen penelitian yang digunakan tentunya telah memenuhi kriteria valid dan reliabel ditinjau dari uji isi. Teknik analisis data yang digunakan dalam penelitian ini adalah teknik analisis statistik deskriptif, yaitu statistik yang digunakan untuk menganalisis data dengan cara mendeskripsikan atau menggambarkan data yang telah terkumpul baik itu melalui tabel, grafik, perhitungan mean dan perhitungan persentase (Sugiyono, 2012). Dalam penelitian ini, seluruh subjek akan dikelompokkan kedalam 3 tingkatan baik untuk kemampuan pemecahan masalah matematika ataupun selfconfidance, yaitu, tinggi, sedang, dan rendah. Untuk mengetahui gambaran umum tentang kemampuan pemecahan masalah matematika dan self-confidance peserta didik dapat dianalisis dengan menggunakan Mean Ideal dan Standar Deviasi Ideal. langkahlangkah pengubahan skor menjadi kriteria penilaian yaitu sebagai berikut (Natanael, 2013):

a. Menentukan Mean Ideal

$$
M_{i}=\frac{1}{2}\left(S M_{i}+\text { Skor Minimum ideal }\right)
$$

b. Menentukan Standar Deviasi

$$
\begin{aligned}
& S D_{i}=\frac{1}{6}\left(S M_{i}-\text { Skor Minimum Ideal }\right) \\
& \text { Keterangan: } \\
& M_{i}=\text { Mean ideal } \\
& S D_{i}=\text { Standar Deviasi }
\end{aligned}
$$


Berdasarkan poin a dan b, maka dapat diperoleh tabel pengkategorian untuk setiap tingkatan kategori seperti pada tabel 2 dan 3 di bawah ini (Turmuzi, 2016):

Tabel 2 Tingkat Kemampuan Pemecahan Masalah Matematika

\begin{tabular}{cc}
\hline Skala & Kategori \\
\hline $75 \leq X_{1} \leq 100$ & Tinggi \\
$50 \leq X_{1}<75$ & Sedang \\
$0 \leq X_{1}<50$ & Rendah \\
\hline
\end{tabular}

Tabel 3 Tingkat Self-Confidance Peserta Didik

\begin{tabular}{cc}
\hline Skala & Kategori \\
\hline $42,67 \leq X_{2} \leq 64$ & Tinggi \\
$21.33 \leq X_{2}<42.67$ & Sedang \\
$X_{2}<21.33$ & Rendah \\
\hline
\end{tabular}

Untuk mengukur kemampuan pemecahan masalah ditinjau dari self-confidance diperlukan beberapa indikator yang tersaji pada tabel 4 dibawah ini:

Tabel 4 Indikator Self-Confidance dan Kemampuan Pemecahan Masalah Matematika

\begin{tabular}{|c|c|c|c|}
\hline No & $\begin{array}{c}\text { Langkah Menurut } \\
\text { Polya }\end{array}$ & $\begin{array}{c}\text { Indikator Pemecahan Masalah } \\
\text { Matematika }\end{array}$ & $\begin{array}{l}\text { Indikator Self- } \\
\text { Confidance }\end{array}$ \\
\hline 1. & $\begin{array}{c}\text { Memahami } \\
\text { Masalah } \\
\text { (Understanding the } \\
\text { Problem) }\end{array}$ & $\begin{array}{l}\text { Mempu menentukan apa yang } \\
\text { diketahui dan apa yang } \\
\text { ditanyakan pada masalah. } \\
\text { Mampu menuliskan dan } \\
\text { menjelaskan masalah dengan } \\
\text { Bahasa dan kalimat sendiri. }\end{array}$ & $\begin{array}{l}\text { a. Percaya pada } \\
\text { kemampuan diri } \\
\text { sendiri. } \\
\text { b. Bertindak mandiri } \\
\text { dalam mengambil } \\
\text { keputusan. }\end{array}$ \\
\hline 3. & $\begin{array}{l}\text { Merencanakan } \\
\text { Rencana }\end{array}$ & $\begin{array}{llr}\text { Mampu } & \text { menentukan } & \text { rencana } \\
\text { yang } & \text { digunakan } & \text { untuk } \\
\text { menyelesaikan masalah. } & \end{array}$ & $\begin{array}{l}\text { c. Memiliki konsep } \\
\text { diri yang positif. } \\
\text { d. Berani }\end{array}$ \\
\hline 4. & $\begin{array}{l}\text { Penyelesaian } \\
\text { (Devising a Plan) }\end{array}$ & $\begin{array}{lll}\text { Mampu menentukan } & \text { rumus } \\
\text { yang } & \text { digunakan } & \text { untuk } \\
\text { menyelesaikan masalah. } & \end{array}$ & $\begin{array}{l}\text { mengungkapkan } \\
\text { pendapat. }\end{array}$ \\
\hline 5. & $\begin{array}{l}\text { Melaksanakan } \\
\text { Rencana }\end{array}$ & $\begin{array}{l}\text { Mampu menerapkan setiap } \\
\text { langkah yang direncanakan } \\
\text { untuk menyelesaikan masalah. }\end{array}$ & \\
\hline 6. & $\begin{array}{l}\text { Penyelesaian } \\
\text { (Carrying out the } \\
\text { Plan) }\end{array}$ & $\begin{array}{l}\text { Mampu menerapkan setiap } \\
\text { rumus yang telah ditentukan } \\
\text { untuk menyelesikan masalah. }\end{array}$ & \\
\hline 7. & & Mampu menentukan & \\
\hline 8. & $\begin{array}{l}\text { Melihat Kembali } \\
\text { (Looking Back) }\end{array}$ & $\begin{array}{l}\text { kesimpulan dari masalah } \\
\text { Mampu memeriksa kembali } \\
\text { rencana dan perhitungan yang } \\
\text { telah dilakukan. }\end{array}$ & \\
\hline
\end{tabular}




\section{HASIL DAN PEMBAHASAN}

Penelitian ini dilakukan untuk mengetahui tingkat kemampuan pemecahan masalah matematika ditinjau dari self-confidance peserta didik kelas VIII tahun pelajaran 2020/2021. Penelitian ini dilaksanakan pada tanggal 14 - 18 Desember 2020 dengan sampel sebanyak 33 peserta didik kelas VIII K tahun pelajaran 2020/2021 pada materi Sistem Persamaan Linier Dua Variabel.

\subsection{Hasil Uji Instrumen}

\subsubsection{Uji Validitas Isi}

Sebelum digunakan, instrumen tersebut harus divalidasi. Pada penelitian ini, peneliti melakukan uji validitas isi terhadap instrumen penelitian yang akan digunakan. Instrumen penelitian yang digunakan telah disusun berdasarkan Kompetensi Dasar materi sistem persamaan linier dua variabel dan diperiksa oleh validator yang dalam hal ini divalidasi oleh 1 orang dosen ahli yakni Ibu Dr. Laila Hayati, S.Pd. M, Si. Berdasarkan validasi yang telah dilakukan oleh validator, intrumen penelitian yang digunakan dinyatakan valid dan layak untuk digunakan disertai dengan saran dan beberapa perbaikan.

\subsubsection{Uji Reabilitas Instrumen}

Dalam menghitung reabilitas instrumen, peneliti menggunakan rumus Alpha Cronbach. Berikut hasil perhitungan reabilitas intrumen penelitian.

\begin{tabular}{clcc}
\multicolumn{4}{c}{ Tabel 5 Hasil Uji Reabilitas Instrumen } \\
\hline No & \multicolumn{1}{c}{ Instrumen } & $\begin{array}{l}\text { Koefisien } \\
\text { reabilitas }\end{array}$ & Keterangan \\
\hline 1. & Soal Pilihan ganda & 0,66 & Reliabel \\
2. & Soal Uraian & 0,68 & Reliabel \\
3. & Angket Self-Confidance & 0,90 & Reliabel \\
\hline
\end{tabular}

Berdasarkan tabel 5 di atas, dapat diketahui bahwa ketiga instrumen penelitian memiliki $r_{11}>r_{\text {tabel }}$ sebesar 0,60 (Prayitno, 2019). Sehingga, dapat disimpulkan bahwa ketiga instrumen penelitian reliabel.

\subsection{Analisis Statistik Deskriptif}

3.2.1. Hasil Tes Pengetahuan Matematika pada Materi Sistem Persamaan Linier Dua Variabel

Pengelompokan peserta didik dalam tingkat pengetahuan matematika ini didasarkan pada pemberian soal tes pengetahun berupa soal pilihan ganda sehingga diperoleh rata-rata nilai pengetahuan matematika peserta didik kelas VIII K tahun pelajaran 2020/2021 pada materi SPLDV sebesar 76.36 atau dengan kriteria pengetahuan matematika tinggi. Berikut ini disajikan tabel hasil pengelompokkan peserta diddik berdasarkan pengetahuan awal yang dimiliki pada materi SPLDV. 
Tabel 6 Hasil Pengelompokan Tingkat Pengetahuan Matematika

\begin{tabular}{ccccl}
\hline Skala & Kategori & $\begin{array}{c}\text { Banyak } \\
\text { Siswa }\end{array}$ & Persentase & Subjek yang terpenuhi \\
\hline $75 \leq X_{1} \leq 100$ & Tinggi & 23 & $70 \%$ & $\begin{array}{l}\text { S1, S2, S3, S4, S5, S8, } \\
\text { S9, S11, S12, S14, S15, }\end{array}$ \\
& & & & S16, S17, S19, S20, S21, \\
& & & & S24, S25, S26, S27, S29, \\
$50 \leq X_{1}<75$ & Sedang & 7 & $21 \%$ & S1, S7, S10, S13, S18, \\
& & & & S32, S33 \\
$0 \leq X_{1}<50$ & Rendah & 4 & $9 \%$ & S22, S23, S28 \\
Jumlah & & 33 & 100 & \\
\hline
\end{tabular}

Berdasarkan Tabel 6, dapat diketahui bahwa mayoritas peserta didik kelas VIII K Tahun Pelajaran 2020/2021 memiliki tingkat pengetahuan matematika tinggi pada materi SPLDV.

3.2.2. Hasil Tes Kemampuan Pemecahan Masalah Matematika pada Materi Sistem Persamaan Linier Dua Variabel

Berdasarkan penilaian yang telah dilakukan, diperoleh hasil tes kemampuan pemecahan masalah peserta didik pada masing-masing kategori tingkat kemampuan pemecahan masalah seperti yang disajikan pada tabel 7 di bawah ini:

Tabel 7 Persentase Tingkat Kemampuan Pemecahan Masalah Matematika

\begin{tabular}{|c|c|c|c|c|}
\hline Skala & Kategori & $\begin{array}{l}\text { Banyak } \\
\text { Siswa }\end{array}$ & Persentase & $\begin{array}{c}\text { Subjek yang } \\
\text { terpenuhi }\end{array}$ \\
\hline $75 \leq X_{1} \leq 100$ & Tinggi & 6 & $18 \%$ & $\begin{array}{l}\text { S11, S21, S22, S26, } \\
\text { S28, S30 }\end{array}$ \\
\hline $50 \leq X_{2}<75$ & Sedang & 20 & $61 \%$ & 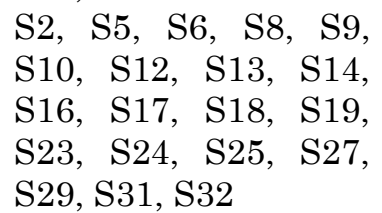 \\
\hline $0 \leq X_{2}<50$ & Rendah & 7 & $21 \%$ & $\begin{array}{l}\text { S1, S3, S4, S7, S15, } \\
\text { S20, S33 }\end{array}$ \\
\hline Jumlah & & 33 & $100 \%$ & \\
\hline
\end{tabular}

Adapun persentase tingkat kemampuan pemecahan masalah matematika peserta didik pada setiap tahapan pemecahan masalah menurut Polya disajikan sebagai berikut: 
Tabel 8 Persentase Tingkat Kemampuan Pemecahan Masalah Matematika

\begin{tabular}{|c|c|c|c|c|c|c|c|}
\hline \multirow[t]{3}{*}{ No } & \multirow{3}{*}{$\begin{array}{c}\text { Tahap Pemecahan } \\
\text { Masalah }\end{array}$} & \multicolumn{6}{|c|}{ Kategori Kemampuan Peserta Didik } \\
\hline & & \multicolumn{2}{|c|}{ Tinggi } & \multicolumn{2}{|c|}{ Sedang } & \multicolumn{2}{|c|}{ Rendah } \\
\hline & & $\mathrm{N}$ & $\mathrm{P}$ & $\mathrm{N}$ & $\mathrm{P}$ & $\mathrm{N}$ & $\mathrm{P}$ \\
\hline 1 & $\begin{array}{l}\text { Memahami } \\
\text { masalah }\end{array}$ & 17 & $52 \%$ & 8 & $24 \%$ & 8 & $24 \%$ \\
\hline 2 & Membuat rencana & 14 & $42 \%$ & 0 & $0 \%$ & 19 & $58 \%$ \\
\hline 3 & $\begin{array}{l}\text { Melaksanakan } \\
\text { rencana }\end{array}$ & 31 & $94 \%$ & 1 & $3 \%$ & 1 & $3 \%$ \\
\hline 4 & Melihat kembali & 1 & $3 \%$ & 23 & $70 \%$ & 9 & $27 \%$ \\
\hline
\end{tabular}

Keterangan

$\mathrm{N}$ = Banyaknya peserta didik dalam setiap tingkatan

$\mathrm{P}=$ Persentase peserta didik dalam setiap tingkatan

\subsubsection{Hasil Kuisoner Self-Confidance}

Berdasarkan penilaian yang telah dilakukan, diperoleh hasil angket self-confidance peserta didik pada masing-masing kategori. Adapun persentase tingkat selfconfidance peserta didik kelas VIII K dapat dilihat pada tabel 9 di bawah ini:

Tabel 9 Persentase Tingkat Self-Confidance Peserta Didik

\begin{tabular}{|c|c|c|c|c|}
\hline Skala & $\begin{array}{c}\text { Kategori } \\
\text { T. K }\end{array}$ & $\begin{array}{c}\text { Banyak } \\
\text { Siswa }\end{array}$ & Persentase & $\begin{array}{c}\text { Sampel yang } \\
\text { terpenuhi }\end{array}$ \\
\hline $42.67 \leq X_{2} \leq 64$ & Tinggi & 18 & $55 \%$ & $\begin{array}{l}\mathrm{S} 5, \mathrm{~S} 7, \mathrm{~S} 8, \mathrm{~S} 9, \\
\mathrm{~S} 10, \mathrm{~S} 11, \mathrm{~S} 13, \\
\mathrm{~S} 14, \mathrm{~S} 18, \mathrm{~S} 19, \\
\mathrm{~S} 21, \mathrm{~S} 22, \mathrm{~S} 25, \\
\mathrm{~S} 26, \mathrm{~S} 27, \mathrm{~S} 29, \\
\mathrm{~S} 30, \mathrm{~S} 32\end{array}$ \\
\hline $21.33 \leq X_{2}<42.67$ & Sedang & 11 & $33 \%$ & $\begin{array}{l}\mathrm{S} 1, \mathrm{~S} 2, \mathrm{~S} 3, \mathrm{~S} 4, \\
\mathrm{~S} 6, \mathrm{~S} 12, \mathrm{~S} 17, \\
\mathrm{~S} 20, \mathrm{~S} 24, \mathrm{~S} 28, \\
\mathrm{~S} 31\end{array}$ \\
\hline $0 \leq X_{3}<21.33$ & Rendah & 4 & $12 \%$ & $\begin{array}{l}\text { S15, S16, S23, } \\
\text { S33 }\end{array}$ \\
\hline Jumlah & & 33 & $100 \%$ & \\
\hline
\end{tabular}

Keterangan: $X_{3}=$ Nilai peserta didik

3.2.4. Pengelompokkan Tingkat Kemampuan Pemecahan Masalah Ditinjau dari Tingkat Self-Confidance Peserta Didik

Berdasarkan hasil analisis tes kemampuan pemecahan masalah matematika dan self-confidance peserta didik yang telah dilakukan sebelumnya, dapat dilakukan pengelompokkan kemampuan pemecahan masalah matematika peserta didik berdasarkan self-confidance seperti pada tabel kontingensi di bawah ini: 
Tabel 10 Tabel Kontingensi Self-confidance dan Kemampuan Pemecahan Masalah Matematika

\begin{tabular}{ccccc}
\hline Self-Confidance & \multicolumn{3}{c}{$\begin{array}{c}\text { Kemampuan Pemecahan } \\
\text { Masalah Matematika }\end{array}$} & Jumlah \\
& Tinggi & Sedang & Rendah & \\
\hline Tinggi & 5 & 12 & 1 & 18 \\
Sedang & 1 & 6 & 4 & 11 \\
Rendah & 0 & 2 & 2 & 4 \\
Jumlah & 6 & 20 & 7 & 33 \\
\hline
\end{tabular}

Berdasarkan analisis data yang telah dilakukan, maka diperoleh hasil rerata nilai kemampuan pemecahan masalah matematika dari masing-masing tingkatan self-confidance seperti pada tabel 11 di bawah ini:

Tabel 11 Rerata Nilai Kemampuan Pemecahan Masalah Matematika di masingmasing tingkatan Self-Confidance

\begin{tabular}{cccc}
\hline Tingkat Self-Confidance & \multicolumn{3}{c}{ Kemampuan Pemecahan Masalah Matematika } \\
& Total Nilai & Rerata Nilai & Kategori \\
\hline Tinggi & $1.186,46$ & 65,91 & Sedang \\
Sedang & 628,13 & 57,10 & Sedang \\
Rendah & 187,50 & 46,88 & Rendah \\
\hline
\end{tabular}

Berdasarkan tabel 11 di atas, dapat diketahui bahwa tingkat kemampuan pemecahan masalah matematika peserta didik dengan tingkat self-confidance tinggi berada pada tingkat kemampuan yang sedang dengan skor rata-rata 65 , 914. Hal tersebut dikarenakan: 1) peserta didik cukup percaya diri dengan kamampuan sendiri dan memahami materi SPLDV dengan cukup baik; 2) peserta didik cukup berani untuk berpendapat saat menjelaskan model matematika yang sudah dibuat walaupun terkadang masih ragu-ragu saat menjawab pertanyaan; 3) peserta didik mampu bertindak mandiri dalam mengambil keputusan untuk menjawab soal tersebut; 4) namun peserta didik kurang berani mengambil tantangan dalam menyelesaikan soal matematika yang telah diberikan dengan tidak mencoba mencari cara lain untuk menyelesaikan soal tersebut dan tidak mencoba mencari cara untuk melakukan prosedur pengecekan kembali. Jika dibandingkan dengan penelitian-penelitian sebelumnya yaitu penelitian Hidayah (2019) yang menyatakan bahwa peserta didik yang memiliki tingkat self-confidance yang tinggi memiliki kemampuan pemecahan masalah matematis yang tinggi pula dengan memenuhi 4 indikator penilaian Polya dengan lengkap maka penelitian ini masih kurang sesuai. Penelitian ini juga tidak sesuai dengan penelitian sebelumnya yang dilakukan oleh Febriana (2018) dengan hasil penelitian berupa peserta didik yang memiliki self-confidance tinggi mampu memahami masalah dengan menuliskan dan menyebutkan yang diketahui dan ditanyakan dengan tepat, mampu membuat rencana dengan strategi yang tepat, mampu melaksankan stategi sesuai rencana 
dan mampu melaksakan indikator melihat kembali dan menarik kesimpulan. Sedangkan, pada penelitian ini indikator yang dapat dipenuhi dengan cukup baik yaitu indikator 1,2, dan 3 namun masih kurang pada indikator 4, sehingga kemampuan pemecahan masalah matematika yang dimiliki subjek dengan selfconfidance tinggi masuk ke dalam kategori sedang.

Bervariasinya tingkat kemampuan pemecahan masalah matematika yang dimiliki oleh peserta didik dengan tingkat self-confidance tinggi ini disebabkan oleh banyak faktor. Berdasarkan hasil wawancara, mayoritas peserta didik masih belum memahami materi dan prosedur penyelesaian soal dengan baik dikarenakan selama proses pembelajaran daring yang dilakukan, peserta didik hanya menerima materi dalam bentuk soft file dengan lampiran-lampiran soal yang dipelajari secara mandiri. Kesulitan belajar peserta didik ini belum mampu diatasi dengan maksimal seperti ketidakpahaman peserta didik atas materi atau contoh soal yang diberikan, hanya beberapa peserta didik yang bertanya langsung pada guru saat proses pembelajaran daring, sisanya akan bertanya pada teman atau mencari contoh penyelesaian lewat internet, namun masih belum cukup membantu bagi peserta didik untuk lebih memahami materi. Terdapat peserta didik yang tidak mengikuti prosedur penyelesaian dikarenakan kemampuan matematis logis peserta didik yang masih kurang. Menurut Zulkarnain (2019) bahwa kecerdasan logis memuat kemampuan seseorang dalam berpikir secara deduktif dan induktif, berpikir menurut aturan logika, memahami dan menganalisis pola angka-angka, serta memecahkan masalah dengan menggunakan kemampuan berpikir. Sehingga ketika memecahkan suatu masalah matematika peserta didik harus memahami terlebih dahulu masalah yang dihadapi, membutuhkan pemahaman, analisis, perhitungan, dan imajinasi yang baik oleh orang yang memiliki kecerdasan logis matematis.

Untuk tingkat self-confidance sedang, kemampuan pemecahan masalah matematika peserta didik dapat dikategorikan pada tingkat kemampuan yang sedang dengan skor rata-rata 57, 102 dan mencapai dua dari empat indikator penilaian kemampuan pemecahan masalah matematika yaitu indikator memahami masalah dan melaksanakan rencana dengan cukup baik. Hal tersebut dikarenakan: 1) peserta didik cukup percaya diri dengan kamampuan sendiri dan memahami materi SPLDV dengan cukup baik; 2) peserta didik kurang berani dan masih ragu-ragu untuk berpendapat saat menjelaskan model matematika yang sudah dibuat saat wawancara; 3) peserta didik mampu bertindak mandiri dalam mengambil keputusan untuk menjawab soal tersebut; 4) namun peserta didik kurang berani mengambil tantangan dalam menyelesaikan soal matematika yang telah diberikan dengan tidak mencoba mencari cara lain untuk menyelesaikan soal tersebut. Jika dibandingkan dengan penelitian sebelumnya, penelitian ini sesuai dengan hasil penelitian yang dilakukan oleh Febriana (2018) dengan hasil yaitu peserta didik dengan selfconfidance sedang hanya mampu menguasai dua dari empat indikator dengan baik yaitu mampu untuk memahami masalah dengan menyebutkan dan 
menuliskan hal-hal yang diketahui dan ditanyakan, kurang tepat dalam membuat model matematka, melaksankan rencana dengan cukup baik dan kurang mampu melihat kembali dengan hanya menuliskan kesimpulan namun tidak melakukan proses pengecekan jawaban.

Untuk tingkat self-confidance rendah, kemampuan pemecahan masalah matematika peserta didik dapat dikategorikan pada tingkat kemampuan yang rendah dengan skor rata-rata 46,875 . Hal tersebut dikarenakan: 1) peserta didik tidak percaya diri dengan kamampuan sendiri dan kurang memahami materi SPLDV; 2) peserta didik kurang berani dan masih ragu-ragu untuk berpendapat saat menjelaskan model matematika yang sudah dibuat saat wawancara; 3) beberapa peserta didik mampu bertindak mandiri dalam mengambil keputusan untuk menjawab soal namun, terdapat beberapa peserta didik belum bisa merencanakan pemecahan soal tersebut sehingga meminta bantuan pada teman lain untuk mampu menyelesaikan soal yang diberikan; dan 4) peserta didik kurang berani mengambil tantangan dalam menyelesaikan soal matematika yang telah diberikan dengan tidak mencoba mencari cara lain untuk menyelesaikan soal tersebut. Sehingga dapat diketahui bahwa peserta didik hanya mencapai satu dari empat indikator penilaian kemampuan pemecahan masalah matematika yaitu melaksanakan rencana dengan cukup baik.

Penelitian ini sejalan dengan penelitian yang sebelumnya telah dilakukan oleh Febriana (2018) yang menyimpulkan bahwa peserta didik dengan self-confidance rendah hanya mampu menguasai satu dari tiga indikator dengan cukup baik. Selain itu, menurut penelitian yang telah dilakukan oleh Hidayah (2019) yang menyimpulkan bahwa peserta didik dengan self-confidance rendah memiliki tingkat kemampuan pemecahan masalah matematis yang rendah pula dengan tidak mampu memenuhi semua indikator dengan baik.

\section{SIMPULAN}

Berdasarkan hasil dan pembahasan dapat disimpulkan, peserta didik yang memiliki selfconfidance tinggi mempunyai kemampuan pemecahan masalah yang baik dengan mengusai 3 dari 4 indikator yaitu indikator memahami masalah, menyusun rencan dan melaksanakan rencana. Sedangkan, untuk indikator memeriksa kembali, peserta didik pada kelompok ini memiliki kemampuan yang cukup. Selanjutnya, untuk peserta didik yang memiliki self-confidance sedang mempunyai kemampuan pemecahan masalah yang cukup baik dengan mengusai 2 dari 4 indikator yaitu indikator memahami masalah dan melaksanakan rencana. Sedangkan, untuk indikator meyusun rencana dan memeriksa kembali, tingkat kemampuan peserta didik tergolong kurang. Untuk peserta didik yang memiliki self-confidance rendah mempunyai kemampuan pemecahan masalah yang masih kurang dengan mengusai hanya 1 dari 4 indikator yaitu indikator melaksanakan rencana. Sedangkan, untuk indikator memahami masalah,meyusun rencana dan memeriksa kembali, tingkat kemampuan peserta didik tergolong kurang. 


\section{REFERENSI}

Arikunto, S. (2012). Prosedur Penelitian. Jakarta: Rineka Cipta.

Chairani, Z. (2016). Metakognisi siswa dalam Pemecahan Masalah Matematika. Yogyakarta: Deepublish.

Febriana, E. (2018). Analisis Kemampuan Pemecahan Masalah Ditinjau dari Kepercayaan Diri Siswa Kelas XI Pada Materi Program Linier.

Fitri, N. S. ( 2017). Meningkatkan Kemampuan Representasi Matematis melalui Penerapan Model Problem Based Learning. Jurnal DIdaktik Matematika, Vol. 4, No. 1, 59-67.

Ghufron, M. N. (2011). Teori-Teori Psikologi. Yogyakarta: Ar-Ruzz Media.

Hidayah, N. (2019). Analisis Kemampuan Pemecahan Masalah Matematis Ditinjau dari SelfConfidance Siswa Kelas X MA Al Asror Kota Semarang. Universitas Islam Negeri Walisongo.

Natanael, Y. d. (2013). Mahir Menggunakan SPSS secara otodidak. Jakarta: Gramedia.

Prayitno, S. (2019). Buku Ajar Evaluasi Pembelajaran Matematika. Mataram: Penerbit Duta Pustaka Ilmu.

Purnama, S., \& Mertika. (2018). Analisis Kemampuan Pemecahan Masalah Siswa Ditinjau dari Self-Confidance. Journal of Education and Review and Research, 59-63.

Riduwan, \& Akdon. (2013). Rumus dan Data dalam Analisis Statistika. Bandung: Alfabeta.

Siska, Sudardjo, \& Esti Hayu Purnamaningsih. (2003). Kepercayaan Diri dan Kecemasan Komunikasi Interpersonal Pada Mahasiswa. Jurnal Psikologi, Volume 1. No. 2. 67-71.

Sugiyono. (2012). Metodologi Penelitian Pendidikan (Pendekatan Kuantitatif, Kualitatif dan $R \& D)$. Bandung: Alfabeta.

Suryanti, S. (2015). Peningkatan Kepercayaan Diri dan Kemampuan Pemecahan Masalah mahasiswa Pada Mata Kuliah Matematika Diskrit Melalui Discovery Learning. 64-73.

Turmuzi, M. (2016). Evaluasi Proses dan Hasil Belajar Matematika. Mataram: FKIP - Pendidikan Matematika Universitas Mataram.

Zulkarnain, I., \& Nurbiati, I. (2019). Pengaruh Kecerdasan Logis Matematis terhadap kemampuan Pemecahan Masalah. Diskusi Panel Nasional Pendidikan Matematika 2019 (pp. 565-571). Jakarta: Universitas Indraprasta PGRI. 